\title{
Study of Biocompatible Films
}

\author{
and Nonwoven Membranes Made of Copolymer \\ of 3-hydroxybutyric Acid \\ and 4-hydroxybutyric Acid in vitro
}

\author{
Natalia V. Borovkova ${ }^{a}$, \\ Anatoly K. Evseev ${ }^{a}$, Maksim S. Makarova, \\ Irina V. Goroncharovskaya ${ }^{a}$, Olga N. Vinogradovab, \\ Elena D. Nikolaeva ${ }^{\mathrm{b} *}$ and Dmitry B. Goncharov ${ }^{\mathrm{b}}$ \\ ${ }^{a}$ N.V. Sklifosovsky Institute of Emergency Care \\ 3 Bolshaya Suharevskaya sq.. Moscow, 129090, Russia \\ ${ }^{b}$ Siberian Federal University \\ 79 Svobodny, Krasnoyarsk, 660049, Russia
}

Received 06.11.2015, received in revised form 20.12.2015, accepted 09.02.2016

\begin{abstract}
Results of studies of films and nonwoven membranes made of a copolymer of 3-hydroxybutiric and 4-hydroxybutyric acid [P(3HB/4HB)] as a models for wound dressings are presented. Structure and properties of $\mathrm{P}(3 \mathrm{HB} / 4 \mathrm{HB})$ product surface and mechanical properties depending on production method and ultrafine fibers orientation of nonwoven membranes obtained by electrospinning are studied. It is shown in cultures of mouse fibroblasts NIH $3 T 3$ and diploid cells of human embryonic lines M-22 all the investigated $P(3 H B / 4 H B)$ samples are biocompatible, not cytotoxic in direct contact with cells and provide high adhesion and cell proliferation, as well as maintaining a high physiological activity up to 7 days. The $P(3 H B / 4 H B)$ film samples and the nonwoven membrane are suitable as biotransplantats and wound coverings.
\end{abstract}

Keywords: polyhydroxyalkanoates, copolymers $P(3 H B / 4 H B)$, production, characteristics, fibroblasts cultivation, wound dressing.

DOI: 10.17516/1997-1389-2015-9-1-43-52.

(C) Siberian Federal University. All rights reserved

* Corresponding author E-mail address: nikolaeva-lena@mail.ru 


\title{
Исследование биологической совместимости пленок
}

и нетканых мембран из сополимера 3-гидроксимасляной

и 4-гидроксимасляной кислот в культурах клеток in vitro

\author{
Н.В. Боровкова ${ }^{\text {a }, \text { А.К. Евсеев }}{ }^{\mathrm{a}}$, \\ М.С. Макаров ${ }^{\mathrm{a}}$, И.В. Горончаровская ${ }^{\text {, }}$ \\ О.Н. Виноградова ${ }^{\tilde{\sigma}}$, Е.Д. Николаева ${ }^{\tilde{\sigma}}$, Д.Б. Гончаров ${ }^{\tilde{\sigma}}$ \\ ${ }^{a}$ НИИ скорой помощчи им. Н.В. Склифосовского \\ Россия, 129090, Москва, пл. Большая Сухаревская, 3 \\ ${ }^{6}$ Сибирский федеральный университет \\ Россия, 660041, Красноярск, пр. Свободный, 79
}

В работе представлены результаты исследования пленок и нетканых мембран, изготовленных из сополимера 3-гидроксимасляной и 4-гидроксимасляной кислот [П(ЗГБ/4ГБ)] в качестве модели раневых покрытий. Исследованы структура и свойства поверхности изделий в зависимости от способа получения имеханчческие свойства, накоторыеоказывает влияниеориентированность ультратонких волокон в нетканых мембранах, полученных методом электростатического формования. В культурах фибробластов мыши линии NIH 3 T3 и диплоидных клеток эмбриона человека линии М-22 показано, что все исследованные образиы не проявляют при прямом контакте с клетками иитотоксичности, биосовместимы и обеспечивают высокую адгезию и пролиферацию клеток, а также сохранение высокой физиологической активности до 7 суток. Пленочные образиы и нетканые мембраны из П(ЗГБ/4ГБ) пригодны для конструирования биотрансплантатов в качестве раневых покрытий.

Ключевые слова: полигидроксиалканоаты, сополимер П(ЗГБ/4ГБ), получение, свойства, культивирование фибробластов, раневые покрытия.

\section{Введение}

Материалы для раневых покрытий должны обладать свойствами, необходимыми для лечения конкретного типа повреждения с учетом течения и фазы раневого процесса. Так, в фазе очистки раны покрытие должно поглощать избыточный экссудат и микроорганизмы, населяющие рану. В фазе грануляции материал раневого покрытия должен обеспечивать необходимую влажность среды, стимулировать ангиогенез и заполнение области дефекта коллагеновыми волокнами. В фазе эпителизации необходимо стимули- ровать клеточное деление и восстановление тканей (Минченко, 2003; Абаев, 2006).

В последнее время появилось большое число раневых покрытий, отличающихся по химическому составу основы и входящим в ее состав лекарственным веществам. Лечебные покрытия имеют различные свойства и показания к применению. По устойчивости покрытия подразделяются на биодеградирующие (рассасывающиеся) и биоинертные. Биодеградирующие покрытия в основном изготавливают из природных полимеров различного происхождения, а биоинертные - из 
синтетических материалов. По форме раневые покрытия разделяют на губки, гели и пленочные раневые покрытия, которые получают все большее распространение. Отдельную группу раневых покрытий, применяющихся в комбустиологии, составляют неприлипающие покрытия, не приводящие к дополнительному повреждению раны при удалении или смене раневого покрытия.

До сих пор не существует универсального изделия (препарата), подходящего для использования во всех фазах раневого процесса при ожогах различной глубины. В этой связи актуальное направление исследований - конструирование атравматичных раневых покрытий с использованием новых полимерных материалов. Рассасывающиеся биосовместимые материалы представляют собой один из вариантов создания нетравмирующих сорбирующих покрытий. В данном случае применение покрытий на основе растворимых или биодеградируемых полимеров (полисахаридов, коллагена, яблочной кислоты, смесей аминокислот и т. д.) позволяет избежать повреждения не до конца заживших ран.

Перспективный класс биоразрушаемых природных полимеров микробиологического происхождения - это полимеры гидроксипроизводных алкановых кислот (полигидроксиалканоаты, ПГА). Семейство ПГА представлено полимерами различного химического строения, существенно различающихся физикохимическими свойствами. Среди них различные материалы - от высококристалличных термопластов до конструкционных эластомеров, что определяется химическим строением мономеров, образующих эти полимеры (Sudesh, 2004; Volova et al., 2013).

Сополимеры, образованные мономерами бета- и гамма-производных масляной кислоты, в зависимости от соотношения мономеров различаются физико-механическими свойствами. С увеличением содержания в них мономеров 4-гидроксимасляной кислоты возрастает эластичность получаемых изделий и их привлекательность для разработки биоразрушаемых пленочных раневых покрытий.

Цель настоящего исследования - конструирование и биологическое тестирование экспериментальных образцов раневых покрытий в виде гладких пленок и нетканых мембран, изготовленных из природных разрушаемых полимеров микробного происхождения, образованных мономерами 3-гидроксимасляной и 4-гидроксимасляной кислот [П(ЗГБ/4ГБ)].

\section{Материалы и методы}

Экспериментальные образцы раневых повязок в виде пленок и нетканых мембран получены из высокоочищенных образцов сополимера 3-гидроксимасляной и 4-гидроксимасляной кислот [П(ЗГБ/4ГБ)] с соотношением мономеров как 90:10 мол. \%, синтезированных в Институте биофизики СО РАН в соответствии с Техническими условиями «ТУ 2200-002-38580845-2012 «Сополимер 3-гидроксимасляной и 4-гидроксивалериановой кислот». Материал сертифицирован в органах Федерального агентства по техническому регулированию и метрологии (№ РОСС RU.AЯ08.H007905 (№ 1423201). Зарегистрирована торговая марка материала «Биопластотан» (Регистрационное свидетельство № 315652, 2006).

Изготовление образцов раневых повязок выполнено в соответствии с Техническими условиями ТУ 9390-009-02067876-2014 «Материалы медицинские из биоразрушаемых природных сополимеров 3-гидроксимасляной и 4-гидроксимасляной кислот». Раневые покрытия в виде нетканых мембран, образованных ориентированными и неориентированными ультратонкими волокнами, получены методом электростатического формования 
растворов сополимера в дихлорметане на автоматизированной установке Nanon 01A (MECC Inc., Япония). Гладкие пленки получали методом полива раствора сополимера в дихлорметане на полированную поверхность металла с последующим испарением растворителя в беспылевом боксе.

Толщину образцов измеряли электронным цифровым микрометром «LEGIONER EDM-25-0.001» (Legioner, Китай); микроструктуру поверхности анализировали при помощи электронного микроскопа ТМ 3000 (Hitachi, Япония); предварительно образцы покрывали платиной (при $10 \mathrm{~mA}, 40$ с) на установке для напыления Emitech K575X. Поверхностные характеристики образцов оценивали на приборе для измерения краевых углов DSA-25E (Krüss, Германия) с использованием программного обеспечения DSA-4 для Windows; измеряли краевые углы смачивания; из полученных значений методом Оунса-Вендта-Рабеля-Кьельбле рассчитывали свободную поверхностную энергию, ее дисперсную и полярную составляющие; физико-механические характеристики регистрировали с помощью универсальной разрывной машины Instron 5565 (Великобритания) с регистрацией модуля Юнга (Е, МПа), абсолютной разрывной прочности ( $\sigma, \mathrm{MПа)} \mathrm{и}$ удлинения при разрыве $(\varepsilon, \%)$.

Для работы с культурой клеток из пленок и мембран нарезали фрагменты размером 1,0 х 0,5 см и размещали их на дне лунок культуральных планшетов, которые стерилизовали плазмой $\mathrm{H}_{2} \mathrm{O}_{2}$ в медицинском стерилизаторе Sterrad NX (Johnson\&Johnson, США). В качестве контроля использовали полистирол (пустые лунки культуральных планшетов).

В качестве первичной оценки биологической совместимости полученных образцов использовали клеточные культуры. Оценку проводили с применением теста на цитоток- сичность in vitro (ГОСТ Р ИСО 10993-5-2009 «Изделия медицинские. Оценка биологического действия медицинских изделий. Часть 5. Исследования на цитотоксичность: методы in vitro»). Использовали культуру фибробластов мыши линии NIH 3Т3 и культуру диплоидных клеток эмбриона человека (ЛДКЧ) фибробласты линии М-22. Анализировали морфологию клеток, в том числе их форму, состояние цитоплазматической мембраны, наличие вакуолизации, зернистости, включений, а также культуральные свойства: время адгезии и распластывания клеток на исследуемой поверхности, индекс пролиферации.

Культуральные планшеты с размещенными в них фрагментами образцов пленок или нетканых мембран засевали тестовыми культурами клеток и помещали в $\mathrm{CO}_{2}$-инкубатор. Культивирование проводили в гумидной среде (содержание $\mathrm{CO}_{2}$ составляло 5 \%) при температуре $37{ }^{\circ} \mathrm{C}$. Анализ клеточных культур проводили в течение 12 сут со сменой питательной среды через каждые 3 сут.

Для оценки биосовместимости исследуемых пленок и нетканых мембран ежедневно определяли общее количество прикрепленных клеток на поверхности исследуемых образцов (тыс. на $1 \mathrm{~cm}^{2}$ ). Для этого исследуемый образец извлекали из лунки, удаляли из нее культуральную жидкость и отделяли клетки от поверхности роста смесью 0,25\%-го раствора трипсина и 0,02\%-го раствора Версена. Клетки ресуспендировали в питательной среде и брали пробу для подсчета в камере Фукс-Розенталя. Индекс пролиферации (ИП $\left.{ }_{3}\right)$ рассчитывали как отношение количества клеток в лунке на третьи сутки культивирования к количеству клеток на первые сутки культивирования. Для этого проводили подсчет окрашенных клеток в не менее чем 10 полях зрения с помощью микроскопа Nikon Eclipse 80i при увеличении х10. Проводили 
морфофункциональный анализ культуры фибробластов линии М-22 с помощью метода оценки клеточного компонента биотрансплантатов (Макаров с соавт., 2013), который основан на окрашивании клеток витальными флуорохромными красителями трипафлавином и родамином с последующим анализом во флуоресцентном микроскопе при различном увеличении. Определяли целостность клеточных мембран (ЦКМ, в баллах), которая отражает структурную целостность клеток. Для окрашивания фибробластов линии NIH 3Т3 использовали флуоресцентные красители DAPI (окраска ядерной ДНК) и FITC (окраска цитоплазмы).

\section{Результаты и обсуждение}

Нетканые мембраны, полученные методом электростатического формования полимерных растворов, имели различия в структуре и физико-механических свойствах (рис. 1, табл. 1). Средний диаметр ультратонких неориентированных волокон в мембране составил 2,9 мкм, это превосходит показатель у мембран из ориентированных волокон (2,0 мкм) при близких показателях плотности собственно мембраны. Нетканые мембраны и пленки имели близкие показатели контактного краевого угла смачивания водой (по- рядка $75-77^{\circ}$ ), однако отличались значениями физико-механических характеристик. В особенности это проявлялось при измерении удлинения при разрыве (показатель эластичности изделий): показатели эластичности нетканых мембран на порядок превосходили пленки. Ориентированные мембраны имели более высокие значения механической прочности, характеризуемой по величине модуля Юнга, по сравнению с неориентированными мембранами, но значительно меньше, чем у пленок (табл. 1).

При прямом контакте с исследуемыми образцами раневых покрытий всех типов признаки цитотоксичности в культуре фибробластов мыши линии NIH 3Т3 отсутствовали (рис. 2). Морфология фибробластов, культивируемых на всех образцах, имела незначительные отличия, но без видимых негативных изменений. РЭМ-изображения, демонстрирующие формирование межклеточного матрикса, свидетельствуют о благоприятной среде для клеток на всех исследуемых образцах. Результаты количественного анализа клеток, окрашенных флуоресцентными красителями, показали влияние ориентированности ультратонких волокон на расположение и количество клеток. Фибробласты, выращиваемые на мембранах из ориентированных волокон,

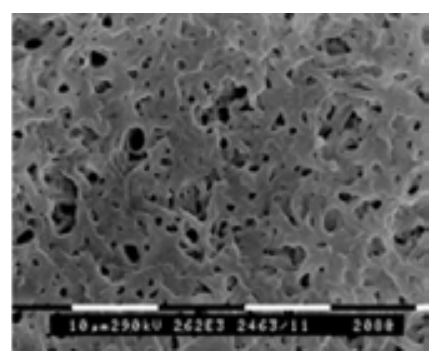

№ 1

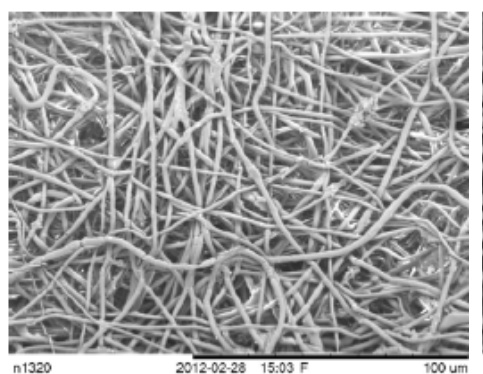

№ 2

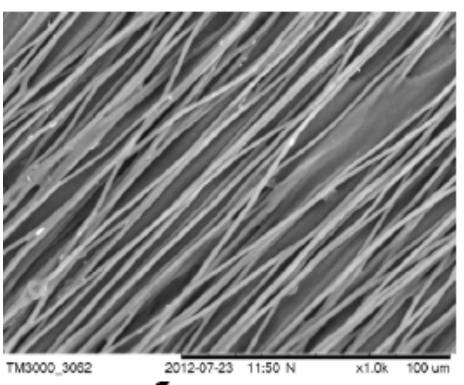

№ 3

Рис. 1. РЭМ-снимки экспериментальных образцов раневых покрытий, изготовленных из сополимера П(ЗГБ/4ГБ): 1 - пленка; 2 - нетканая неориентированная мембрана; 3 - нетканая ориентированная мембрана 


\begin{tabular}{|c|c|c|c|c|}
\hline \multirow{4}{*}{ 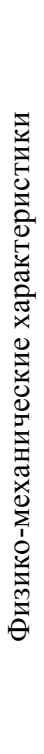 } & 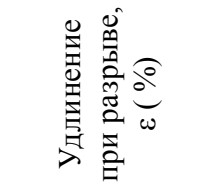 & $\begin{array}{l}n \\
n \\
n_{1} \\
n \\
\hat{n} \\
\hat{0}\end{array}$ & 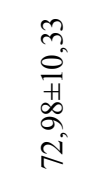 & 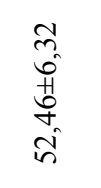 \\
\hline & 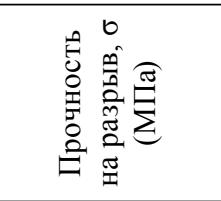 & $\begin{array}{l}1 \\
\infty \\
0 \\
+1 \\
+1 \\
\infty \\
+ \\
= \\
=\end{array}$ & \begin{tabular}{l}
$\infty$ \\
0 \\
0 \\
$\stackrel{+}{H}$ \\
\multirow{2}{0}{}
\end{tabular} & 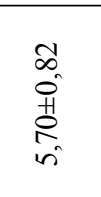 \\
\hline & 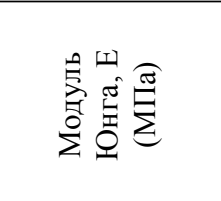 & 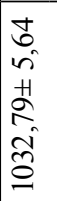 & $\begin{array}{l}0 \\
0 \\
0 \\
0 \\
n \\
n \\
-1\end{array}$ & $\begin{array}{l}\stackrel{2}{2} \\
\stackrel{n}{1} \\
\text { तै } \\
\stackrel{2}{2}\end{array}$ \\
\hline & 兽 & $\stackrel{ \pm}{\sim}$ & $\approx$ & $\ddot{\sim}$ \\
\hline & 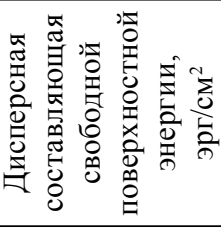 & 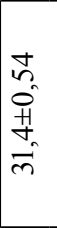 & \begin{tabular}{l}
$\infty$ \\
\multirow{2}{0}{} \\
+1 \\
$\infty$ \\
$\infty$ \\
$\infty$
\end{tabular} & 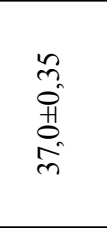 \\
\hline$\Xi$ & 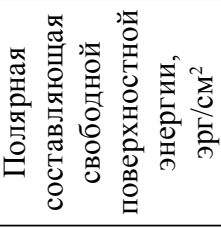 & 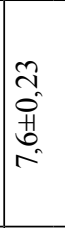 & $\begin{array}{l}\hat{N} \\
\tilde{O} \\
\dot{y} \\
\dot{y}\end{array}$ & $\begin{array}{l}n \\
\tilde{0} \\
\underline{1} \\
0 \\
0\end{array}$ \\
\hline 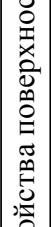 & 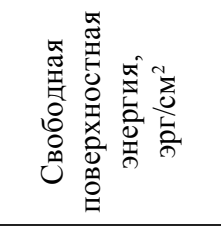 & $\begin{array}{l}0 \\
0 \\
0 \\
+1 \\
0 \\
2\end{array}$ & 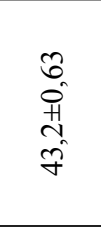 & 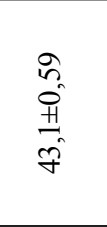 \\
\hline$\infty$ & 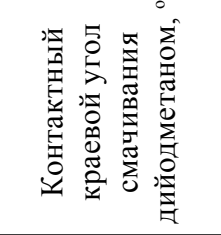 & 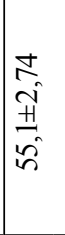 & $\begin{array}{l}\vec{F} \\
\stackrel{H}{H} \\
\stackrel{f}{F}\end{array}$ & $\begin{array}{l}\hat{\sigma} \\
\vec{H} \\
\dot{y} \\
y\end{array}$ \\
\hline & 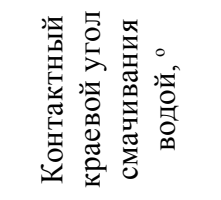 & 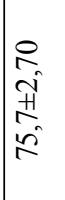 & 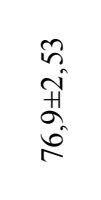 & 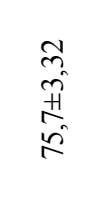 \\
\hline & 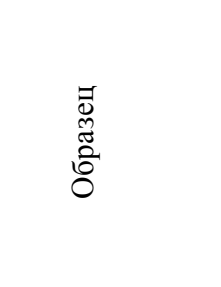 & 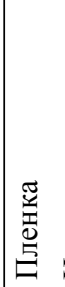 & 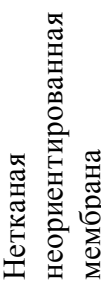 & 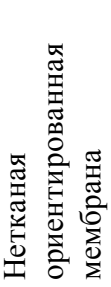 \\
\hline
\end{tabular}


были распределены вдоль волокон и были преимущественно веретеновидной формы. На неориентированных мембранах клетки также распределялись по волокнам, при этом преобладали клетки треугольной формы, с 3-4 отростками, с помощью которых клетки крепились к волокнам. Более крупные клетки зафиксированы на неориентированных мембранах. Так, средние размеры фибробластов, культивируемых на неориентированных мембранах, составили $(429,93 \pm 158)$ мкм $^{2}$, на ориентированных - значительно мельче, $(274,79 \pm 28,59)$ мкм $^{2}$. Количество клеток на неориентированных мембранах было самым высоким - $\left(2,41 \pm 0,20 \cdot 10^{5}\right)$ кл/см². Количество жизнеспособных фибробластов на пленках и ориентированных мембранах было ниже, чем на неориентированных, соответственно $\left(1,41 \pm 0,18 \cdot 10^{5}\right)$ и $\left(1,65 \pm 0,28 \cdot 10^{5}\right)$ кл/см², однако в целом сопоставимым с контролем (культуральные планшеты, полистирол). Таким образом, все типы исследуемых полимерных образцов биосовместимы и пригодны для культивирования клеток, однако для исследуемой линии фибробластов мыши NIH 3T3 наиболее благоприятны пленки и неориентированные нетканые мембраны.

При исследовании экспериментальных образцов раневых покрытий в культуре диплоидных клеток эмбриона человека (фибробласты линии М-22) клетки были прозрачны, четко очерчены и имели характерную для культуры морфологию: не содержали включений, сохраняли свою исходную структурную целостность (рис. 3). Пролиферативная активность клеток не претерпевала видимых изменений на протяжении всего срока культивирования и была сопоставима с контролем (полистирол), что отражено в значениях индекса пролиферации (табл. 2).

Присутствие всех типов образцов изделий из П(ЗГБ/4ГБ) в культуре не оказывало влияния на пролиферативную активность клеток линии М-22 при прямом контакте. При смене среды 1 раз в 3 сут фибробласты линии M-22, адгезированные на поверхности исследуемых полимерных образцов, сохраняли нормальную морфологию, были метаболически активными и размножались без токсических изменений на протяжении всего срока наблюдения (рис. 3).

Процесс заселения всех образцов покрытий клетками линии М-22 был весьма выраженным, начиная с третьих суток культивирования. Так, на гладких пленках отдельные клетки обнаруживались уже через 1 сут культивирования изделий, через 2 сут

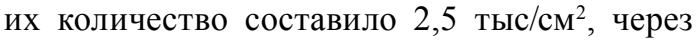
3 сут - 5 тыс/см², через 5 сут - 15 тыс/см², че-

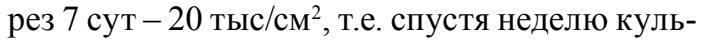
тивирования на поверхности образца был сформирован полноценный конфлюентный

Таблица 2. Индекс пролиферации диплоидных фибробластов человека линии М-22 в контроле и в присутствии раневых покрытий, изготовленных из сополимера П(ЗГБ/4ГБ) (среднее \pm стандартная ошибка, $\mathrm{n}=10$ )

\begin{tabular}{|c|c|c|c|c|}
\hline \multirow[b]{2}{*}{$\begin{array}{l}\text { Номер пассажа } \\
\text { культуры M-22 }\end{array}$} & \multicolumn{4}{|c|}{ Индекс пролиферации на третьи сут } \\
\hline & $\begin{array}{c}\text { Контроль } \\
\text { (полистирол) }\end{array}$ & Пленка & $\begin{array}{c}\text { Нетканая } \\
\text { неориентированная } \\
\text { мембрана }\end{array}$ & $\begin{array}{c}\text { Нетканая } \\
\text { ориентированная } \\
\text { мембрана }\end{array}$ \\
\hline 1 & $1,83 \pm 0,07$ & $1,87 \pm 0,09$ & $1,80 \pm 0,11$ & $2,08 \pm 0,11$ \\
\hline 2 & $2,13 \pm 0,11$ & $2,14 \pm 0,14$ & $2,08 \pm 0,12$ & $2,10 \pm 0,80$ \\
\hline 3 & $1,96 \pm 0,07$ & $1,96 \pm 0,09$ & $1,88 \pm 0,10$ & $1,96 \pm 0,10$ \\
\hline
\end{tabular}



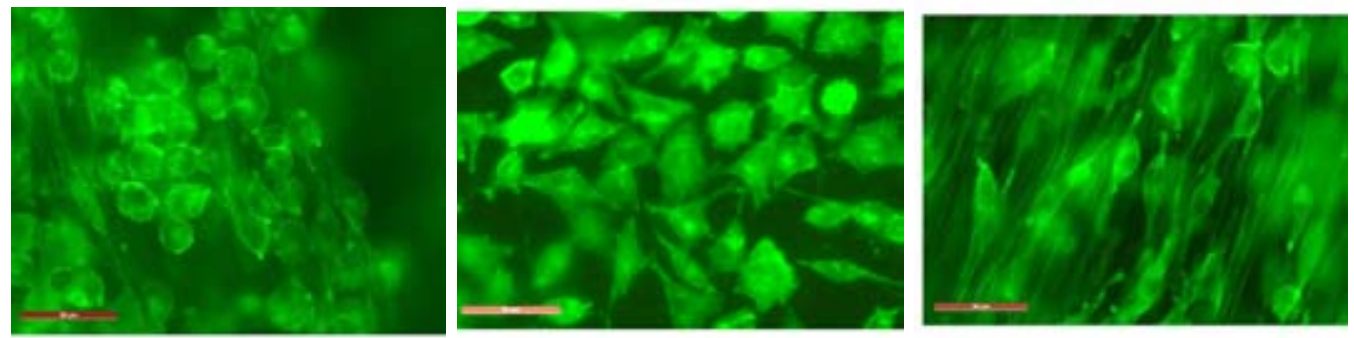

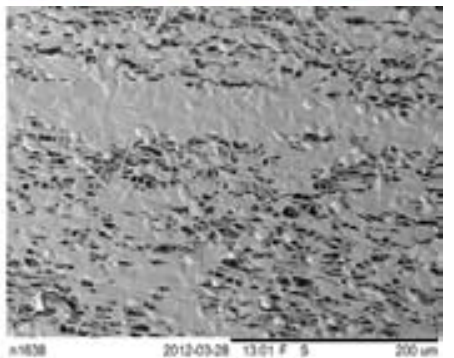

№ 1

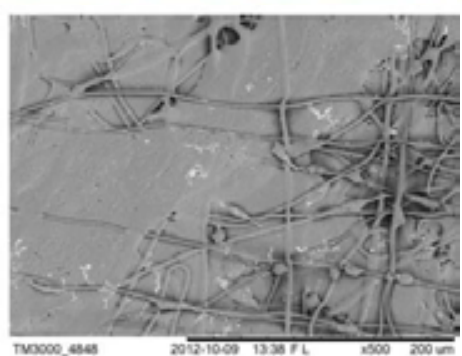

№ 2

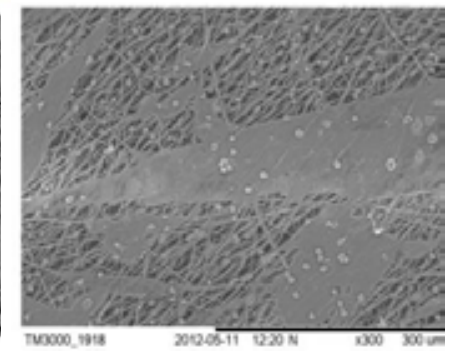

№ 3

Рис. 2. Морфология фибробластов мыши линии NIH 3 T3 (7-суточная культура), выращиваемых на экспериментальных образцах раневых покрытий, изготовленных из сополимера П(ЗГБ/4ГБ): 1 - пленка; 2 - нетканая неориентированная мембрана; 3 - нетканая ориентированная мембрана. Верхний ряд окраска FITC, маркер 50 мкм; нижний ряд - РЭМ-снимки, маркер 200 мкм
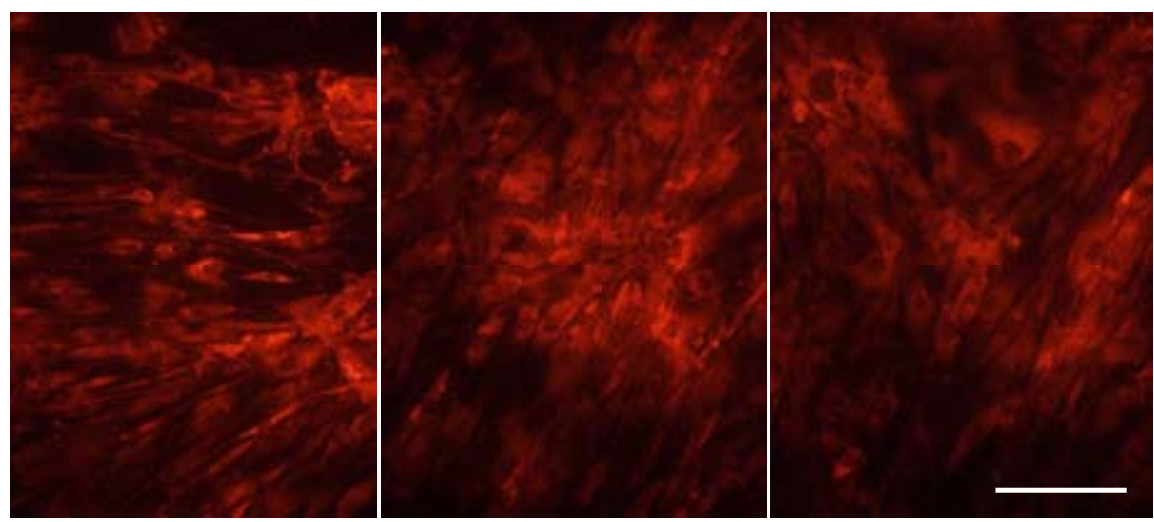

Рис. 3. Морфология фибробластов линии М-22 (7-суточная культура), выращиваемых на экспериментальных образцах раневых покрытий, изготовленных из сополимера П(ЗГБ/4ГБ): 1 - пленка; 2 - нетканая неориентированная мембрана; 3 - нетканая ориентированная мембрана. Витальное окрашивание флуорохромными красителями трипафлавином и родамином С, маркер 50 мкм

(занимающий более 80 \% всей поверхности) монослой клеток (рис. 4).

Клетки имели характерную для них распластанную или фибробластоподобную, реже полигональную, форму и были биологически полноценными. Скорость заселения клетками неориентированной и ориентированной нетканой мембран была ниже. Отдельные клетки были обнаружены на поверхности мембран на третьи сутки культивирования; через 5 сут их количество составило 8 тыс/ $\mathrm{cm}^{2}$, через 7 суток - 16 тыс/см² (субконфлюэнтный монослой); большинство клеток имели не распластанную, а веретеновидную форму 

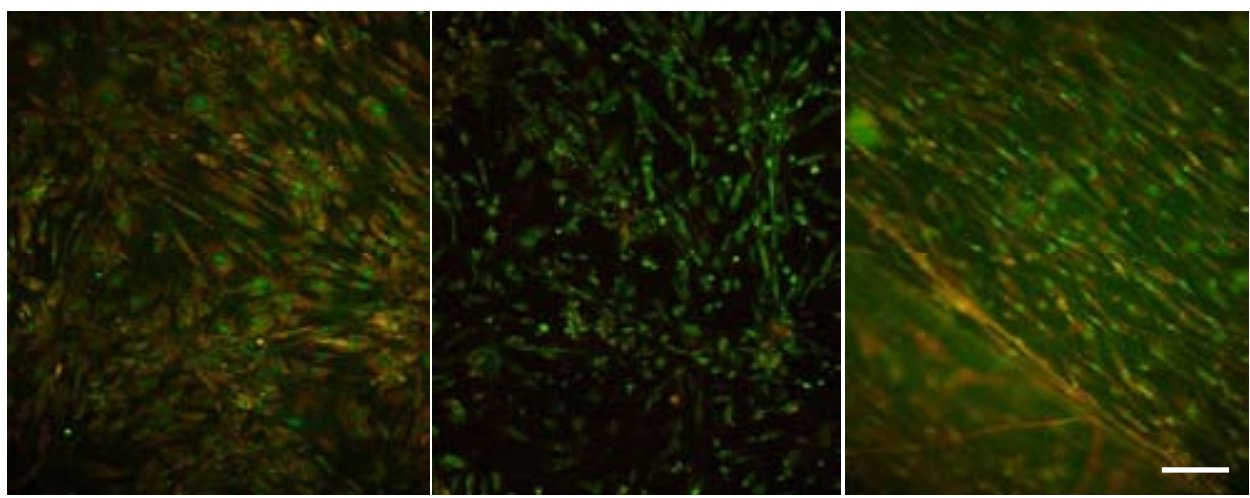

Рис. 4. Морфология фибробластов линии М-22 (7-суточная культура), выращиваемых на экспериментальных образцах раневых покрытий, изготовленных из сополимера П(ЗГБ/4ГБ): 1 - пленка; 2 - нетканая неориентированная мембрана; 3 - нетканая ориентированная мембрана. Суправитальное окрашивание флуорохромными красителями. Маркер 100 мкм

при сохранении целостности их внутреннего состава. Максимальная заселенность пленок и мембран наблюдалась на 7-8-е сут, затем численность клеток начинала постепенно снижаться вплоть до 10-х сут, когда количество клеток на пленках сократилось на 25 \%, на мембранах значительнее - на 30-40 \%. Начиная с 11-х сут наблюдали незначительный рост численности клеток на всех образцах, и численность клеток к исходу 12-х сут достигла уровня 18 тыс/см² на пленках и 12 тыс/см² на мембранах. При этом подавляющее большинство прикрепленных клеток имели характерную для них фибробластоподобную форму.

Таким образом, при стандартных методах культивирования образцы обеспечивают длительное сохранение прикрепленных клеток.

Биологическая полноценность прикрепленных клеток, определяемая параметром целостности клеточных мембран (ЦКМ), сохранялась в течение 7-8 сут с момента начала заселения на высоком уровне: 36,0 баллов для гладких пленок и 36,5 балла для ориентированных и неориентированных нетканых мембран (при норме 28-42 балла). Незначи- тельное снижение значения ЦКМ прикрепленных клеток (30,0 баллов) отмечено на 10-11-е сут культивирования; на этом этапе исследования в популяции клеток отмечено максимальное содержание поврежденных клеток (20 \%). К 12-м сут значения ЦКМ несколько увеличивались и составили 34,6 балла. В то же время доля клеток с нарушениями мембранных компонентов (10\%) была выше, чем на 7-8-е сут (5 \%). Это подтверждает предположение о том, что адекватный срок культивирования клеток на исследуемых образцах в качестве биотрансплантатов кожи не должен превышать 7-8 сут. Важно отметить, что биологическая полноценность клеток сохранялась в течение 7-8 сут после заселения всех образцов.

\section{Заключение}

Разработаны и охарактеризованы экспериментальные раневые покрытия в виде гладких наливных пленок и нетканых мембран, сформированных ориентированными и неориентированными ультратонкими волокнами, полученных методом электростатического формования растворов разрушаемого сополимера П(ЗГБ/4ГБ). Биологическая 
совместимость и отсутствие цитотоксичности всех типов экспериментальных раневых покрытий установлены в культурах клеток двух линий (фибробластов мыши линии NIH 3Т3 и диплоидных клеток эмбриона человека линии М-22). Все образцы обеспечивают вы- сокую адгезию, рост клеток и сохранение высокой физиологической активности до 7 сут. Пленочные образцы и нетканые мембраны из П(ЗГБ/4ГБ) пригодны для конструирования биотрансплантатов в качестве раневых покрытий.

Работа выполнена за счет средств государственного задания на проведение фундаментальных исследований РАН (проект № гос. регистрации 01201351505).

\section{Список литературы}

Абаев Ю.К. (2006) Раны и раневая инфекиия: Справочникхирурга. М., Феникс, 427 с. [Abaev Yu.K. (2006) Wounda and wound infection. Manual of surgeon. Moscow, Feniks, 427 p. (in Russian)] ГОСТ Р ИСО 10993-5-2009 «Изделия медицинские. Оценка биологического действия медицинских изделий. Часть 5. Исследования на цитотоксичность: методы in vitro» [GOST R ISO 10993-5-2009 "Medical devices. Biological evaluation of medical devices. Part 5. Cytotoxicity studies: methods of in vitro » (in Russian)]

Макаров М.С., Конюшко О.И., Сторожева М.В., Боровкова Н.В., Хватов В.Б., Пономарев И.Н. Метод морфофункциональной оценки клеточного компонента биотрансплантатов. Патент РФ на изобретение № 2484472 от 10.06.2013 [Makarov M.S., Konyushko O.I., Storozheva M.V., Borovkova N.V., Hvatov V.B., Ponomarev I.N. The method of morphological and functional evaluation of the cellular component of biotransplantats. RF patent number 2484472 on 06.10 .2013 (in Russian)]

Минченко А.Н. (2003) Раны. Лечение и профилактика осложнений. СПб., СпецЛит, 216 c. [Minchenko A.N. (2003) Wounds. Treatment and prevention of complications. Sankt Petersburg, SpecLit, 216 p. (in Russian)]

Торговая марка «БИОПЛАСТОТАН». Регистрационное свидетельство № 315652 Федерального института патентной экспертизы по заявке № 2006703271/50, приоритет от 15.02.2006. Классы МКТУ: 01, 05, 10. [Brand "BIOPLASTOTAN". The registration certificate number 315652 of Federal Institute of Patent Examination of application № 2006703271/50, a priority from 15.02.2006. The classes of the Nice Classification: 01, 05, 10 (in Russian)]

Sudesh K. (2004) Microbial polyhydroxyalkanoates (PHAs): an emerging biomaterial for tissue engineering and therapeutic applications. Medical Journal of Malaysia, 59: 55-66

Volova T.G., Shishatskaya E.I., Sinskey A.J. (2013) Degradable Polymers: Production, Properties and Applications. Nova Science Publisher, 387 p. 